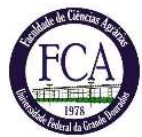

Revista Agrarian

ISSN: 1984-2538

\section{Quality and physiological changes of basil after hydrocooling and storage in two temperatures}

\author{
Qualidade e mudanças fisiológicas do manjericão após hidroresfriamento e armazenamento em duas \\ temperaturas
}

\author{
Lara Nascimento Guimarães ${ }^{1}$, Paula Cristina Carvalho Lima ${ }^{2}$, Fernando Luiz Finger ${ }^{2}$ \\ ${ }^{1}$ Instituto Federal Goiano - Campus Morrinhos (IFG). Rodovia BR153, KM633 - Zona Rural, Morrinhos - \\ GO, CEP 75650-000. E-mail: larinhapnn@hotmail.com \\ ${ }^{2}$ Universidade Federal de Viçosa (UFV).
}

Recebido em: 07/11/2017

Aceito em:02/05/2018

\begin{abstract}
Basil is an aromatic plant, with spice, medicinal and ornamental potential. As the basil leaves are susceptible to rapid dehydration after harvest, heat removal by the pre-cooling technique may be an alternative to increase the shelf life of the product. Thus, the aim of this study was to evaluate two storage temperature ( 5 ${ }^{\circ} \mathrm{C}$ and $\left.25^{\circ} \mathrm{C}\right)$ and hydrocooling in a mixture of ice and water in the proportion of $1: 3(\mathrm{v} / \mathrm{v})$ at $4{ }^{\circ} \mathrm{C}(0,5$ and 10 minutes of exposure times) on qualitative and physiological changes of 'Roxinho' basil after storage. Data were analyzed as a split plot design, the plots corresponding to treatments and the sub-plots storage times, in completely randomized design, with three replications, each experimental unit was a package containing $25 \mathrm{~g}$ of basil branches. The variables cumulative mass loss, relative water content, chlorophyll content and fraction of water-soluble phenols were evaluated. The basil branches stored at $5{ }^{\circ} \mathrm{C}$ showed lower weight losses and greater relative water content when compared to storage at $25^{\circ} \mathrm{C}$. Treatments with hydrocooling maintained higher chlorophyll contents during storage, slowing tissue senescence. Hydrocooling for 5 minutes followed by storage at $5{ }^{\circ} \mathrm{C}$ was efficient in extending basil branches shelf life, keeping quality and physiological aspects of the product to the $4^{\text {th }}$ day of storage.
\end{abstract}

Keywords: Ocimum basilicum L., shelf life, storage, cooling, chlorophyll.

Resumo: O manjericão é uma planta aromática, com potencial condimentar, medicinal e ornamental. Como as folhas de manjericão são suscetíveis à rápida desidratação logo após a colheita, a remoção do calor pela técnica de pré-resfriamento pode ser uma alternativa para aumentar a vida de prateleira do produto. Sendo assim, o objetivo deste trabalho foi avaliar duas temperaturas de armazenamento $\left(5{ }^{\circ} \mathrm{C}\right.$ e $\left.25{ }^{\circ} \mathrm{C}\right)$ e hidroresfriamento em uma mistura de gelo e água na proporção de $1: 3(\mathrm{v} / \mathrm{v})$ a $4{ }^{\circ} \mathrm{C}(0,5$ e 10 minutos de tempos de exposição) em mudanças qualitativas e fisiológicas de manjericão ‘Roxinho' após armazenamento. As informações foram analisadas em parcelas subdivididas, as parcelas correspondem aos tratamentos e as sub-parcelas aos tempos de armazenamento, em delineamento inteiramente casualizado, com três repetições, sendo cada unidade experimental uma embalagem contendo $25 \mathrm{~g}$ de ramos de manjericão. Foram avaliadas as variáveis perda de massa cumulativa, teor relativo de água, conteúdo de clorofila e fração de fenóis solúveis. Os ramos de manjericão armazenados a $5{ }^{\circ} \mathrm{C}$ mostraram menores perdas de massa e maior teor relativo de água quando comparado ao armazenamento em $25^{\circ} \mathrm{C}$. Os tratamentos com hidroresfriamento mantiveram maiores concentrações de clorofila durante o armazenamento, retardando a senescência dos tecidos. $O$ hidroresfriamento por 5 minutos seguido de armazenamento a $5{ }^{\circ} \mathrm{C}$ foi eficiente em conservar os ramos de manjericão, mantendo aspectos qualitativos e fisiológicos do produto até o $4^{\circ}$ dia de armazenamento.

Palavras-chave: Ocimum basilicum L., vida de prateleira, armazenamento, resfriamento, clorofila.

\section{Introduction}

The basil (Ocimum basilicum L.) is an aromatic plant with cultivation focused on the essential oil production, fresh and dried leaves, spice, medicinal and its ornamental use (Filip et al., 2014). In addition to its medicinal properties, this species is valued in the international market, in the cosmetics and food industry due to the high 


\section{(-) \\ Revista Agrarian \\ ISSN: 1984-2538}

concentration of linalool in its essential oil (Kakaraparthi et al., 2015). Besides, the consumption of fresh basil leaves markedly increase glutathione S-transferase activity that partly controls chemical carcinogens in the stomach, liver, and oesophagus (Aruna \& Sivaramakrishnan, 1990).

In Brazil, the average dry mass production of the total shoots parts of basil in one year of cultivation is around 3 tons per hectare ${ }^{-1}$, but can reach up to 33 tons per hectare ${ }^{-1}$ of dry mass of the total shoots parts ( 165 tons per hectare ${ }^{-1}$ fresh mass per year), being 15 tons per hectare ${ }^{-1}$ of dry leaves (May et al., 2017). In view of high yields, efficient storage methods are necessary, since plant storability depends on temperature, exposure time, species, cultivar and exposed organ (Bekhradi et al., 2015).

Postharvest deterioration during storage it is the biggest cause of vegetables losses resulting in significant economic losses (Sivakumar and Bautista-Baños, 2014). Leafy vegetables are highly perishable and highly susceptible to water loss, which can be intensified by inadequate handling of temperature and air humidity in storage and marketing places, with consequent reduction in shelf life and increase in the final cost of the product to consumers (Álvares et al., 2007). Thus, it is necessary to consume immediately or apply conservation techniques to decrease metabolic activity and prolong shelf life.

One of the main objectives in postharvest technology is to delay the onset of symptoms of senescence in vegetables. Postharvest losses of leaf species can be reduced using refrigerated storage, maintaining high relative humidity (90-95\%), modified atmosphere and precooling. Hydroooling contributes to the fruits and vegetables conservation, because it quickly removes the field heat, before the product is transported, stored, marketed or processed. Respiratory rates, ethylene production, senescence and microbial activity can be reduced by rapid heat withdrawal (KalbasiAshtari, 2004).

However, tropical and subtropical vegetables, as basil plants are chilling sensitive when stored at temperatures below $12{ }^{\circ} \mathrm{C}$, characterized by brown discoloration of the middle areas of the leaf, stem browning and collapse, wilting of the leaves and loss of glossy appearance and characteristic aroma (Cozzolino et al., 2016; Fratianni et al., 2017), but many works that used hydrocooling methods and low storage temperatures $\left(5\right.$ to $7{ }^{\circ} \mathrm{C}$ ), showed maintenance of the quality and extension of shelf life in leafy vegetables such as, coriander leaves (Oliveira et al., 2015; Souza et al., 2017), parsley leaves (Álvares et al., 2007; Alvares et al., 2010) and lettuce (França et al., 2015).

The aim of this study was to evaluate two storage temperature $\left(5{ }^{\circ} \mathrm{C}\right.$ and $\left.25{ }^{\circ} \mathrm{C}\right)$ and hydrocooling $(0,5$ and 10 minutes of exposure times) on qualitative and physiological changes of 'Roxinho' basil after storage.

\section{Material and Methods}

The experiment was carried out at Federal University of Viçosa (UFV), Viçosa, Minas Gerais State, Brazil $\left(20^{\circ} 45^{\prime} \mathrm{S}, 42^{\circ} 52^{\prime} \mathrm{W}\right.$, altitude $\left.648 \mathrm{~m}\right)$ using basil (Ocimum basilicum L.), cultivar 'Roxinho', grown in greenhouse, following all cultural management recommended until commercial harvesting time. Harvesting of branches was performed during the morning, in January of 2017, being transported immediately to the laboratory, where branches with no signs of wilt, yellowing or any incidence of decay were selected.

Hydrocooling was performed by immersing the basil branches in a mixture of ice and water in the proportion of $1: 3(\mathrm{v} / \mathrm{v})$ at $4{ }^{\circ} \mathrm{C}$. Basil branches, after selection, were submitted to following treatments: $\mathrm{T} 1=$ hydrocooling for 5 minutes followed by storage at $5{ }^{\circ} \mathrm{C}$ in cold chamber; $\mathrm{T} 2=$ hydrocooling for 5 minutes followed by storage at $25{ }^{\circ} \mathrm{C}$; $\mathrm{T} 3=$ hydrocooling for 10 minutes followed by storage at $5{ }^{\circ} \mathrm{C}$ in cold chamber; $\mathrm{T} 4=$ hydrocooling for 10 minutes followed by storage at $25{ }^{\circ} \mathrm{C}$; T $5=$ storage in cold chamber at $5{ }^{\circ} \mathrm{C}$ without hydrocooling and $\mathrm{T} 6=$ storage at $25^{\circ} \mathrm{C}$ without hydrocooling. The storage of branches, for both temperatures, was performed in polyethylene terephthalate perforated containers $(19 \times 12 \times 4.9 \mathrm{~cm})$.

Cumulative mass loss was estimated in relation to initial fresh weight, before storage, being carried out every 12 hours during the 96 hours of storage. The results are expressed as percentage of fresh weight loss, as follows: $\mathrm{FWL}=$ $100-((\mathrm{FFW} * 100) / \mathrm{IFW})$. Wherein: $\mathrm{FWL}=$ fresh weight loss (\%); FFW = final fresh weight (g) and IFW $=$ initial fresh weight $(\mathrm{g})$.

Relative water content (RWC) was evaluated every 24 hours, using five leaves, 


\section{Revista Agrarian}

ISSN: 1984-2538

according method described by Barr and Weatherley (1962) and mentioned by Álvares et al. (2010), according to the equation: $\mathrm{RWC}=[(\mathrm{FW}-$ $\mathrm{DW} /(\mathrm{TW}-\mathrm{DW})]$ x 100, where: $\mathrm{FW}=$ fresh weight (g); DW= dry weight (g); TW= turgid weight (g).

Chlorophyll content in the leaves was evaluated every 24 hours during storage, using three leaves discs from the branches, these are weighed and placed in screw-tubes containing $5 \mathrm{~mL}$ of N,N-Dimethylformamide, under refrigeration at $4{ }^{\circ} \mathrm{C}$ in the dark. After ten days, the chlorophyll content was determined according to the methodology described Inskeep and Bloom (1985), in spectrophotometer Genesys 10S UV-VIS (Thermo Scientific, Massachusetts, EUA), with readings at 647 and $664.5 \mathrm{~nm}$ wavelengths. The results are expressed according to the equation: Total chlorophyll (mg.L $\left.\mathrm{L}^{-1}\right)=17.9 \mathrm{~A}_{647}+8.08 \mathrm{~A}_{664.5}$. With subsequent conversion to $\mathrm{mg} / \mathrm{g}^{-1}$, as follows: $\mathrm{mg} \cdot \mathrm{g}^{-1}=$ Total Chlorophyll x 0,05)/fresh weight of the disks.

The fraction of water-soluble phenols was evaluated every 24 hours during storage, from $0.3 \mathrm{~g}$ tissue homogenized with a mixture of methanol-acetic acid-water to 50: 3.7: $46.3(\mathrm{v} / \mathrm{v})$. After, the samples were centrifuged at $16,000 \mathrm{~g}$ for 15 minutes, and a $0.2 \mathrm{~mL}$ fraction of the supernatant was mixed with $1 \mathrm{ml}$ of FolinCiocalteau reagent diluted $(1: 10)$ and kept at room temperature for 10 minutes (Fu et al., 2010). Then, was mixed with $0.8 \mathrm{ml}$ of $7.5 \%$ sodium carbonate and incubated at room temperature for 30 minutes in the dark. The absorbance was recorded at 760 $\mathrm{nm}$ using gallic acid as standard and the results are expressed at $\mathrm{mg}$ gallic acid. $\mathrm{g}^{-1}$ basil leaves tissue.
Data were analyzed as a split plot design, the plots corresponding to treatments and the subplots storage times, in completely randomized design, with three replicates, each experimental unit was a package containing $25 \mathrm{~g}$ of basil branches. The means of the analyzed parameters were submitted to the Tukey test with a 5\% level of error probability and statistical analysis was performed using Sisvar software (Ferreira, 2011). The results of cumulative weight loss and relative water content during the storage were analyzed using a regression analysis. The mean of the chlorophyll content and fraction of water-soluble phenols during the storage were submitted to the standard error of the mean $(n=3)$. SigmaPlot 10.0 software was used for graph design.

\section{Results and Discussion}

Basil branches without hydrocooling and stored at $25{ }^{\circ} \mathrm{C}$ showed fresh mass loss significantly higher during storage time when compared to other treatments, while the lowest a loss was observed in the hydrocooling treatment for 5 minutes followed by storage stored at $5{ }^{\circ} \mathrm{C}$ (Table 1, Figure 1). Linear increase of fresh weight loss was observed during storage at 5 and at $25^{\circ} \mathrm{C}$, with or without hydrocooling (Figure 1). The fresh mass loss in vegetables can be attributed to the evaporation of water retained after washing, due to respiration consisting of the carbohydrates oxidation to carbon dioxide and water and due to dehydration, which is the water loss due to the difference in water vapor pressure between the interior of the plant and the surrounding environment (Moreira et al., 2006).

Table 1. Means of cumulative weight loss (\%), relative water content (\%), total chlorophyll content (mg. $\left.\mathrm{g}^{-1}\right)$ and fraction of water-soluble phenols (mg gallic acid. $\mathrm{g}^{-1}$ ) of basil branches 'Roxinho' in function of treatment.

\begin{tabular}{|c|c|c|c|c|c|c|c|c|}
\hline \multirow{2}{*}{$\begin{array}{l}\text { Hydrocooling } \\
\text { time }\end{array}$} & \multicolumn{2}{|c|}{$\begin{array}{c}\text { Cumulative mass } \\
\text { loss }\end{array}$} & \multicolumn{2}{|c|}{$\begin{array}{c}\text { Relative water } \\
\text { content }\end{array}$} & \multicolumn{2}{|c|}{$\begin{array}{c}\text { Chlorophyll } \\
\text { content }\end{array}$} & \multicolumn{2}{|c|}{$\begin{array}{l}\text { Fraction of water- } \\
\text { soluble phenols }\end{array}$} \\
\hline & $5^{\circ} \mathrm{C}$ & $25^{\circ} \mathrm{C}$ & $5^{\circ} \mathrm{C}$ & $25^{\circ} \mathrm{C}$ & $5^{\circ} \mathrm{C}$ & $25^{\circ} \mathrm{C}$ & $5^{\circ} \mathrm{C}$ & $25^{\circ} \mathrm{C}$ \\
\hline $0 \mathrm{mir}$ & $\begin{array}{c}30.92 \\
\mathrm{aB}\end{array}$ & $\begin{array}{c}35.12 \\
\mathrm{aA}\end{array}$ & $\begin{array}{c}73.19 \\
\mathrm{aA}\end{array}$ & $\begin{array}{c}68.31 \\
\mathrm{aA}\end{array}$ & $\begin{array}{c}19.61 \\
\mathrm{bA}\end{array}$ & $\begin{array}{c}19.94 \\
\mathrm{cA}\end{array}$ & $2.66 \mathrm{aA}$ & $2.98 \mathrm{aA}$ \\
\hline 5 minutes & $\begin{array}{c}26.57 \\
\mathrm{bB}\end{array}$ & $\begin{array}{c}30.17 \\
\mathrm{bA}\end{array}$ & $\begin{array}{c}79.49 \\
\mathrm{aA}\end{array}$ & $\begin{array}{c}69.39 \\
\mathrm{aB}\end{array}$ & $\begin{array}{c}21.34 \\
\mathrm{aA}\end{array}$ & $\begin{array}{c}22.45 \\
\text { bA }\end{array}$ & $2.73 \mathrm{aA}$ & $2.67 \mathrm{aA}$ \\
\hline 10 minutes & $\begin{array}{c}27.14 \\
\text { abB }\end{array}$ & $\begin{array}{c}33.03 \\
\text { abA }\end{array}$ & $\begin{array}{c}73.55 \\
\mathrm{aA}\end{array}$ & $\begin{array}{c}68.75 \\
\text { aA }\end{array}$ & $\begin{array}{c}21.91 \\
\mathrm{aB}\end{array}$ & $\begin{array}{c}23.81 \\
\mathrm{aA}\end{array}$ & $\mathrm{aA}$ & $2.72 \mathrm{aA}$ \\
\hline
\end{tabular}

Averages followed by the same lowercase letters in the column do not differ by Tukey test $(\mathrm{p} \leq 0.05)$ and averages followed by the same uppercase letters in the line for each analyzed variable do not differ by Tukey test $(\mathrm{p} \leq 0.05)$. 


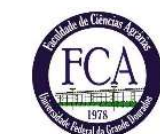

Revista Agrarian

ISSN: $1984-2538$

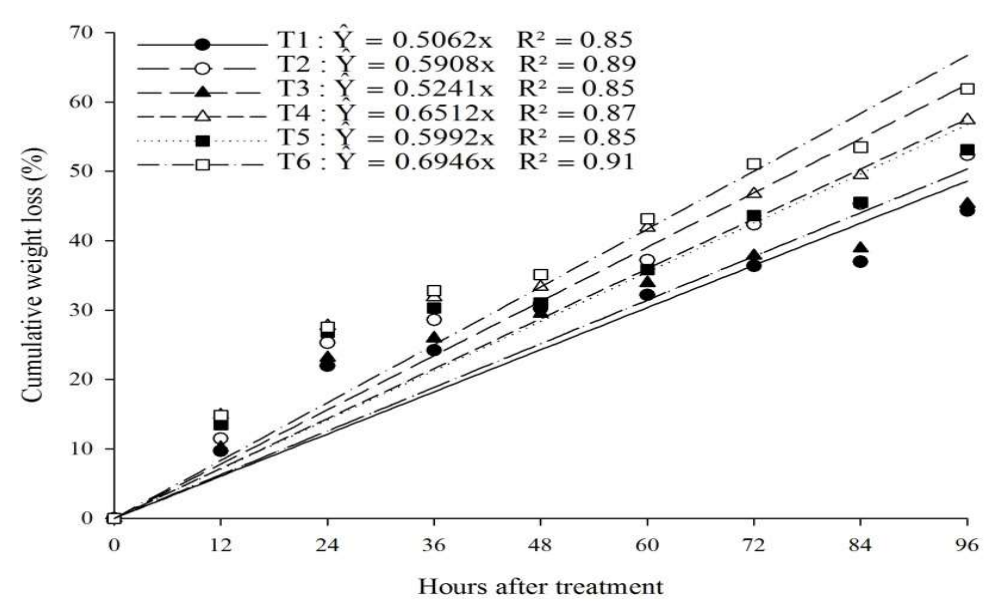

Figure 1. Cumulative weight loss (\%) of basil branches 'Roxinho' in function of treatment and stored time. $\mathrm{T} 1=$ hydrocooling for 5 minutes followed by storage at $5{ }^{\circ} \mathrm{C}$ in cold chamber; $\mathrm{T} 2=$ hydrocooling for 5 minutes followed by storage at $25^{\circ} \mathrm{C}$; $\mathrm{T} 3=$ hydrocooling for 10 minutes followed by storage at $5{ }^{\circ} \mathrm{C}$ in cold chamber; $\mathrm{T} 4=$ hydrocooling for 10 minutes followed by storage at $25^{\circ} \mathrm{C}$; T5= storage in cold chamber at $5{ }^{\circ} \mathrm{C}$ without hydrocooling and $\mathrm{T} 6=$ storage at $25{ }^{\circ} \mathrm{C}$ without hydrocooling.

Hydrocooled basil branches stored at refrigerated condition shown lower values of mass loss, they were visually more turgid than other treatments, and this turgescense visually observed can be proven by higher relative water content (Table 1, Figure 2). Turgor is an essential factor in determining the shelf life of leafy vegetables. In basil branches with hydrocooled treatment for 5 minutes stored at 5 and $25^{\circ} \mathrm{C}$, mass loss rate per hour was $0.27 \%$ (6.5\% per day) and $0.31 \%$ ( $7.6 \%$ per day), respectively, and hydrocooling treatment for 10 minutes stored at 5 and $25^{\circ} \mathrm{C}$, showed mass loss rate per hour of $0.28 \%$ (6.8\% per day) and $0.35 \%$ ( $8.4 \%$ per day), respectively. Basil branches treatment without hydrocooling stored at 5 and 25 ${ }^{\circ} \mathrm{C}$, mass loss rate per hour was, $0.32 \%$ ( $7.8 \%$ per day) and $0.37 \%$ ( $8.9 \%$ per day), respectively. Therefore, data shows a higher degree of dehydration of the leaves in storage conditions at $25{ }^{\circ} \mathrm{C}$ compared to storage at $5{ }^{\circ} \mathrm{C}$. Usually, leafy vegetables present elevated water loss, because high initial temperatures cause high dehydration losses, as dehydration is related to heat transfer efficiency, depends of their specific surface area, where the water loss through transpiration directly affects the appearance and the weight of the product, enhancing the progress of senescence (Álvares et al., 2010). 


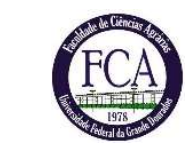

Revista Agrarian

ISSN: 1984-2538

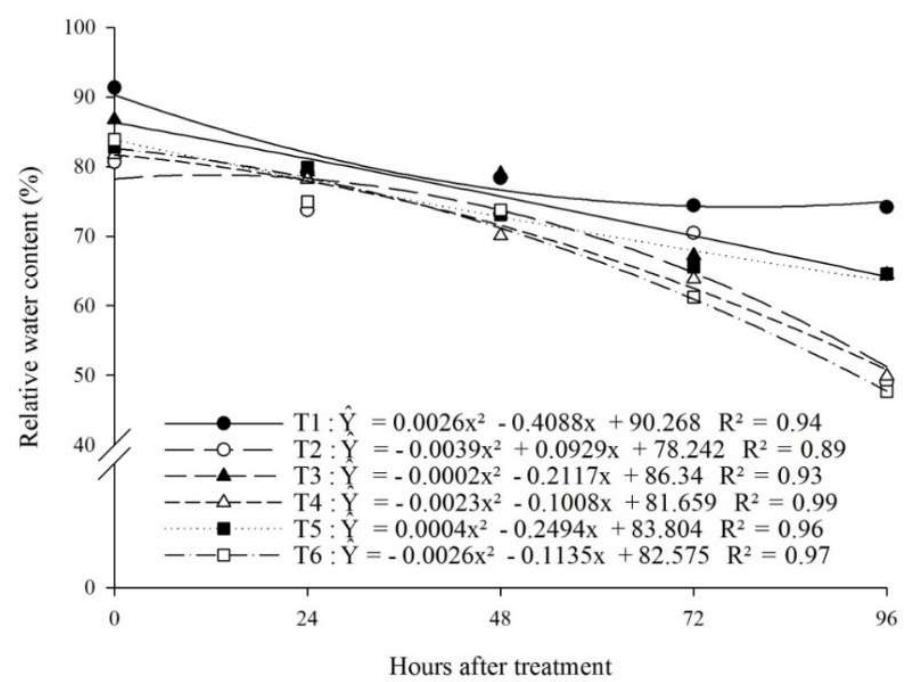

Figure 2. Relative water content (\%) of basil leaves 'Roxinho' in function of treatment and stored time. $\mathrm{T} 1=$ hydrocooling for 5 minutes followed by storage at $5{ }^{\circ} \mathrm{C}$ in cold chamber; $\mathrm{T} 2=$ hydrocooling for 5 minutes followed by storage at $25{ }^{\circ} \mathrm{C}$; $\mathrm{T} 3=$ hydrocooling for 10 minutes followed by storage at $5{ }^{\circ} \mathrm{C}$ in cold chamber; $\mathrm{T} 4=$ hydrocooling for 10 minutes followed by storage at $25^{\circ} \mathrm{C}$; $\mathrm{T} 5=$ storage in cold chamber at $5{ }^{\circ} \mathrm{C}$ without hydrocooling and $\mathrm{T} 6=$ storage at $25^{\circ} \mathrm{C}$ without hydrocooling.

After 96 hours (4 days) only hydrocooling treatment for 5 minutes followed by storage at $5{ }^{\circ} \mathrm{C}$ showed better leaves turgescence (Figure 2). This result confirms the importance of hydrocooling treatment, which has high efficiency due to the high thermal conductivity of water, in addition to the uniform contact between water and the surface of the product, which promotes rapid reduction in temperature (Tsang and Furutani, 2006). However, the maintenance of the cold chain also increases the products shelf life, because of the reduction in temperature providing lower water vapor pressure gradient between the plant and the environment, minimizing water losses. Cooling operates by decreasing the respiratory rate, ethylene production, and the intensity of senescence and microbial activity (Kalbasi-Ashtari, 2004).

Hydrocooling treatment for 5 minutes stored at $5{ }^{\circ} \mathrm{C}$ showed relative water content higher than other treatments (Table 1, Figure 3), these data support the increased leaf turgescence and freshness appearance observed during storage for this treatment. For packages stored at cooled conditions $\left(5^{\circ} \mathrm{C}\right)$, there was an average decrease of $22 \%$ in the relative water content of the leaves during the 96 hours of evaluation, while stored at $25{ }^{\circ} \mathrm{C}$, there average decrease of $40 \%$ during the 96 hours of evaluation, probably due of the higher vapor pressure gradient established at $25{ }^{\circ} \mathrm{C}$ that accelerates water loss of leaves (Figure 3 ). 


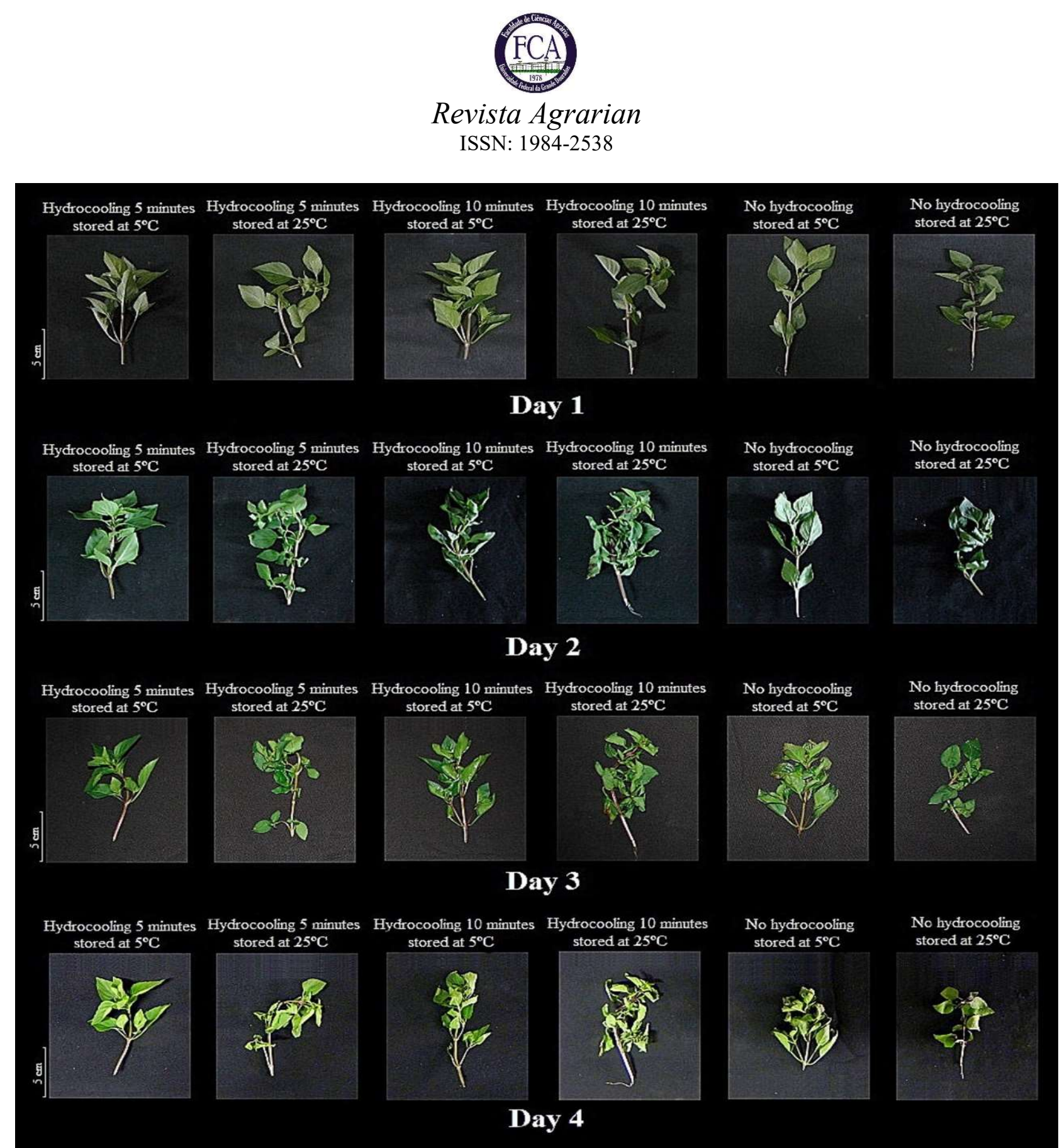

Figure 3. Appearance of basil branches 'Roxinho' in function of treatment and stored time.

The hydrocooling for 5 minutes followed by storage at $5{ }^{\circ} \mathrm{C}$ is an effective technique to maintain the leave water balance, keeping these leaves hydrated for a longer period of time during storage. Álvares et al. (2007), studying the effect of pre-cooling for parsley, observed higher relative water content in hydrocooled leaves, when compared to control, during all storage time at 5 ${ }^{\circ} \mathrm{C}$. Álvares et al. (2010) observed longer shelf life of parsley leaves when it was stored in cooled condition, which proves the importance of keeping the cold chain in order to preserve food security of horticultural products. Lettuce (Lactuca sativa) stored under refrigeration $\left(5^{\circ} \mathrm{C}\right)$ and wrapped in perforated polyethylene plastic bags, preserved the appearance quality for longer, regardless the application of other treatment for postharvest conservation (França et al., 2015). In the coriander conservation, regardless of the use of hydrocooling $5^{\circ} \mathrm{C}$ and relative humidity of $81 \%$, there was a delay in the loss of fresh matter over the shelf life, when compared to at $20^{\circ} \mathrm{C}$ (Oliveira et al., 2015).

During storage linear increase of chlorophyll content per unit mass was observed during storage at 5 and at $25{ }^{\circ} \mathrm{C}$, with or without hydrocooling (Figure 4). As for the average values during storage, significant changes in chlorophyll content occurred, where the highest values were observed in hydrocooling treatments, regardless of 


\section{(-) \\ Revista Agrarian \\ ISSN: 1984-2538}

the storage temperature (Table 1). This result is contradictory to others of the literature, which reported chlorophyll reduction with storage period, as Oliveira et al. (2015) using SPAD index, that observed yellowing of coriander leaves with hydrocooling during storage, which may be related to coriander intolerance immediate reduction in leaf temperature, result of the rapid cooling imposed by the hydrocooling. Already Álvares et al. (2007) using SPAD index, found that the use of pre-cooling followed by $5{ }^{\circ} \mathrm{C}$ on parsley leaves (Petroselinum crispum) did not stimulate chlorophyll degradation, and França et al. (2015) also did not observe effect of hydrocooling treatment and storage time for the chlorophyll content in lettuce leaves. However, the data obtained agree with Thewes et al. (2016) who observed increase in chlorophyll content of native and cultivated yerba mate quality during shelf life after long-term storage at $20^{\circ} \mathrm{C}$, increasing the chlorophyll content may be due to the formation of other compounds which have absorbance comparable to the chlorophyll molecule, decreases in oxidation of the chlorophyll molecule or due to excessive water loss by the leaves, because even if there remobilization and chlorophyll degradation, there is a concentration of this pigment in the chloroplasts.

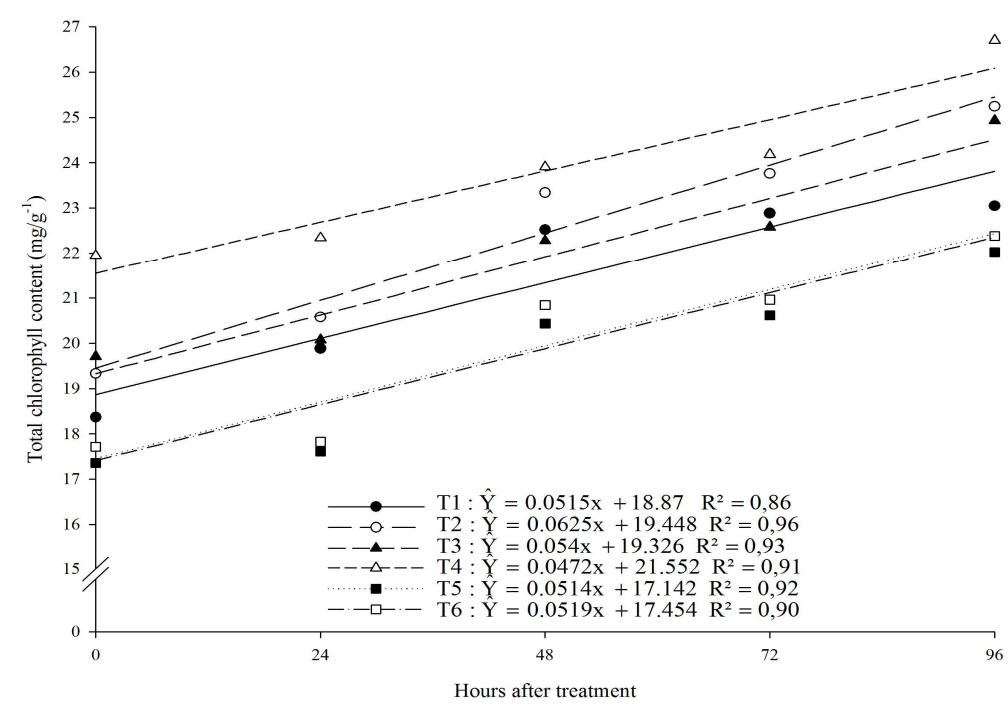

Figure 4. Total chlorophyll (mg.g $\left.\mathrm{g}^{-1}\right)$ of basil leaves 'Roxinho' in function of treatment and stored time. T1 $1=$ hydrocooling for 5 minutes followed by storage at $5{ }^{\circ} \mathrm{C}$ in cold chamber; $\mathrm{T} 2=$ hydrocooling for 5 minutes followed by storage at $25{ }^{\circ} \mathrm{C} ; \mathrm{T} 3=$ hydrocooling for 10 minutes followed by storage at $5{ }^{\circ} \mathrm{C}$ in cold chamber; $\mathrm{T} 4=$ hydrocooling for 10 minutes followed by storage at $25{ }^{\circ} \mathrm{C}$; $\mathrm{T} 5=$ storage in cold chamber at $5{ }^{\circ} \mathrm{C}$ without hydrocooling and $\mathrm{T} 6=$ storage at $25^{\circ} \mathrm{C}$ without hydrocooling.

During storage there were no changes in fraction of water-soluble phenols in both evaluated treatments, showing average values of $2.75 \mathrm{mg}$ gallic acid $\mathrm{g}^{-1}$ on basil leaves (Table 1), the regression analysis showed quadratic behavior with accumulation peaks at 48 hours of storage (Figure 5), this is probably due to the higher oxidative stress in the leaves, since water-soluble phenols are potent antioxidants able to carry out the sequestration of reactive oxygen species (Siboza et al., 2014). Phenolic compounds make up a large and diverse group of bioactive compounds, including several different families of aromatic secondary metabolites in plants that may occur in three forms, free, soluble conjugate and insoluble bound (Kaisoon et al., 2011). 


\section{(-) \\ Revista Agrarian \\ ISSN: 1984-2538}

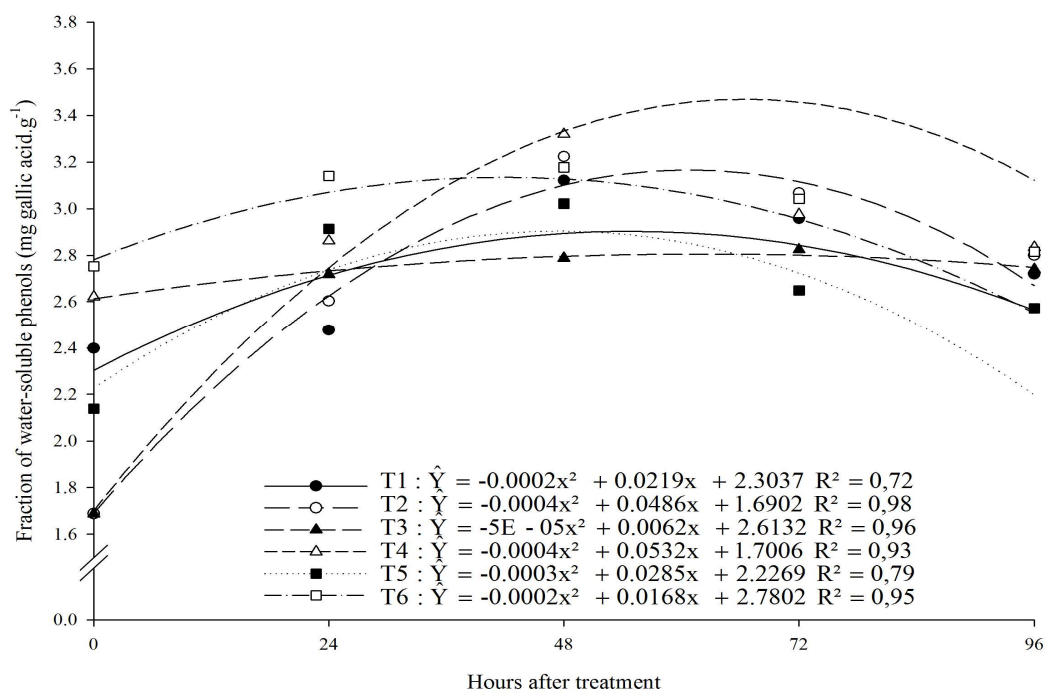

Figure 5. Fraction of water-soluble phenols (mg gallic acid. $\left.\mathrm{g}^{-1}\right)$ of basil leaves 'Roxinho' in function of treatment and stored time. $\mathrm{T} 1=$ hydrocooling for 5 minutes followed by storage at $5{ }^{\circ} \mathrm{C}$ in cold chamber; $\mathrm{T} 2=$ hydrocooling for 5 minutes followed by storage at 25 ${ }^{\circ} \mathrm{C}$; $\mathrm{T} 3=$ hydrocooling for 10 minutes followed by storage at $5{ }^{\circ} \mathrm{C}$ in cold chamber; $\mathrm{T} 4=$ hydrocooling for 10 minutes followed by storage at $25^{\circ} \mathrm{C}$; T5= storage in cold chamber at $5{ }^{\circ} \mathrm{C}$ without hydrocooling and $\mathrm{T} 6=$ storage at $25^{\circ} \mathrm{C}$ without hydrocooling.

According Teruel et al. (2002), the hydrocooling can promote temperature lowering three times faster than other procedures. In general, the use of hydrocooling as a postharvest conservation technique was efficient in delaying the deterioration of many products, for example, preservation of shelf life of coriander leaves up to the $8^{\text {th }}$ day of storage at $7^{\circ} \mathrm{C}$ (Souza et al., 2017), promoted longer shelf life of butter lettuce stored at 5 and $22^{\circ} \mathrm{C}$ and kept higher water content in leaves stored at $5{ }^{\circ} \mathrm{C}$ (França et al., 2013), and the use of plastic packaging associated to the hydrocooling method contributed, significantly, for the postharvest conservation of basil leaves, obtaining a shelf life of up to the $7^{\text {th }}$ day (Teixeira et al., 2016).

\section{Conclusions}

Postharvest storage of basil with or without hydrocooling at room temperature is not a viable option in relation to losses of cumulative fresh weight. Basil branches stored at $5{ }^{\circ} \mathrm{C}$ shows better turgescence and appearance of leaves when compared to storage at $25^{\circ} \mathrm{C}$, possibly due to the decrease of the vapor pressure gradient between the product and the surrounding environment. Besides that, hydrocooling treatments showed higher chlorophyll content during storage when compared to treatments without hydrocooling. Hydrocooling for 5 minutes followed by storage at $5{ }^{\circ} \mathrm{C}$ was efficient in conserving basil branches, because the low temperatures no caused signs of browning characteristic of chilling injury, keeping quality and physiological aspects of the product to the $4^{\text {th }}$ day of storage, being an alternative of low economic cost for the conservation of the product in open markets, supermarkets and consumers residences.

\section{References}

ÁLVARES, V.S.; NEGREIROS, J.R.S.; RAMOS, P.A.S.; MAPELI, A.M.; FINGER, F.L. Préresfriamento e embalagem na conservação de folhas de salsa. Brazilian Journal of Food Technology, v.13, n.2, p.107-111, 2010. ÁLVARES, V.S.; FINGER, F.L; SANTOS, R.C.A.; NEGREIROS, J.R.S.; CASALI, V.W. Effect of pre-cooling on the postharvest of parsley leaves. Journal of Food, Agriculture and Environment, v.5, n.2, p.31-34, 2007.

ARUNA, K.; SIVARAMAKRISHNAN, V. M. Plant products as protective agents against cancer. Indian Journal of Experimental Biology, v.28, n.11, p.1008-1011, 1990. 


\section{(a) \\ Revista Agrarian \\ ISSN: 1984-2538}

BARR, H.D. and WEATHELEY, P.E. A reexamination of the relative turgidity technique for estimating water deficit in leaves. Australian Journal of Biological Sciences, v.15, n.3, p.413428, 1962.

BEKHRADI, F.; LUNA, M.C.; DELSHAD, M.; JORDAN, M.J.; SOTOMAYOR, J.A.; MARTÍNEZ-CONESA, C.; GIL, M.I. Effect of deficit irrigation on the postharvest quality of different genotypes of basil including purple and green Iranian cultivars and a Genovese variety. Postharvest Biology and Technology, v.100, p.127-135, 2015.

COZZOLINO, R., PACE, B.; CEFOLA, M.; MARTIGNETTI, A.; STOCCHERO, M.; FRATIANNI, F.; NAZZARO, F.; DE GIULIO, B. Assessment of volatile profile as potential marker of chilling injury of basil leaves during postharvest storage. Food Chemistry, v.213, p.361-368, 2016. FERREIRA, D.F. Sisvar: a computer statistical analysis system. Ciência e Agrotecnologia, v.35, n.6, p.1039-1042, 2011.

FILIP, S.; VIDOVIC, S.; ADAMOVIC, D.; ZEKOVIC, Z. Fractionation of non-polar compounds of basil (Ocimum basilicum L.) by supercritical fluid extraction (SFE). Journal of Supercritical Fluids, v.86, p.85-90, 2014.

FRANÇA, C.F.M.; RIBEIRO, W.S.; SILVA, F.C.; COSTA, L.C.; RÊGO, E.R.; FINGER, F.L. Hydrocooling on postharvest conservation of butter lettuce. Horticultura Brasileira, v.33, n.3, p.383-387,

2015.

FRATIANNI, F.; CEFOLA, M.; PACE, B.; COZZOLINO, R.; DE GIULIO, B.; COZZOLINO, A.; D'ACIERNO, A.; COPPOLA, R.; LOGRIECO, F.; NAZZARO, F. Changes in visual quality, physiological and biochemical parameters assessed during the postharvest storage at chilling or non-chilling temperatures of three sweet basil (Ocimum basilicum L.) cultivars. Food Chemistry, v.229, p.752-760, 2017.

FU, L.; XU, B.T.; XU, X.R.; QUIN, X.S.; GAN. R.Y.; LI, H.B. Antioxidant capacities and total phenolic contents of 56 wild fruits from South China. Molecules, v.15, n.12, p.8602-8617, 2010. INSKEEP, W.P. and BLOOM, P.R. Extinction coefficients of chlorophyll $a$ and $b$ in $\mathrm{N}, \mathrm{N}$ Dimethylformamide and $80 \%$ acetone. Plant Physiology, v.77, n.2, p.483-485, 1985.

KAISOON, O.; SIRIAMORNPUN, S.; WEERAPREEYAKUL, N.; MEESO, N. Phenolic compounds and antioxidant activities of edible flowers from Thailand. Journal of functional foods, v.3, n.2, p.88-99, 2011.

KALBASI-ASHTARI, A. Effects of post-harvest pre-cooling processes and cyclical heat treatment on the physico-chemical properties of "Red Haven Peaches" and "Shahmavch Pears" during cold storage. Agricultural Engineering International, v.6, p.1-17, 2004.

KAKARAPARTHI, P. S.; SATYA SRINIVAS, K.V.N.; KOTESH KUMAR, J.; KUMAR, N.A.; KUMAR, A. Composition of herb and seed oil and antimicrobial activity of the essential oil of two varieties of Ocimum basilicum harvested at short time intervals. Journal of Plant Development, v.22, p.59-76, 2015.

MAY, A.; PINEHIRO, M. Q.; SACCONI, L. V.; JESUS, J. P. F. Manjericão (Ocimum basilicum L.). Instituto Agronômico - IAC Centro de Análise e Pesquisa Tecnológica do Agronegócio de Horticultura. 4p. Available in: $<$ http://www.iac.sp.gov.br/imagem_informacoeste cnologicas/40.pdf $>$ Access in: 11/12/2017.

MOREIRA, M.D.R.; PONCE, A.G; DEL VALLE, C.E.; ANSORENA, R.; ROURA, S.S. Effects of abusive temperatures on the postharvest quality of lettuce leaves: ascorbic acid loss and microbial growth. Journal of Applied Horticulture, v.8, n.2, p.109-113, 2006.

OLIVEIRA, L.S.; SILVA, T.P.; FERREIRA, A.P.S.; PEREIRA, A.M.; FINGER, F.L. Efeito do hidroresfriamento na conservação pós-colheita de coentro. Horticultura Brasileira, v.33, n.4, p.457461, 2015.

SIBOZA, X.I.; BERTLING, I.; ODINDO, A.O. Salicylic acid and methyl jasmonate improve chilling tolerance in cold-stored lemon fruit (Citrus limon). Journal of Plant Physiology, v.171, n.18, p.1722-1731, 2014.

SIVAKUMAR, D. and BAUTISTA-BAÑOS, S. A review on the use of essential oils for postharvest decay control and maintenance of fruit quality during storage. Crop Protection, 64:27-37, 2014. SOUZA, M.T.A.; SANCHES, A.G.; MOREIRA, E.G.S.; CORDEIRO, C.A.M. Eficiência do hidroresfriamento na conservação e qualidade póscolheita de coentro (Coriandrum sativum L.). Revista Trópica - Ciências Agrárias e Biológicas, v.10, n.1, p.32-40, 2017.

TEIXEIRA, D.A.; GOMES, J.A.O.; BONFIM, F.P.G.; PARDO, P.I.; MAYOBRE, M.T. Técnicas de conservação pós-colheita para o manjericão. 


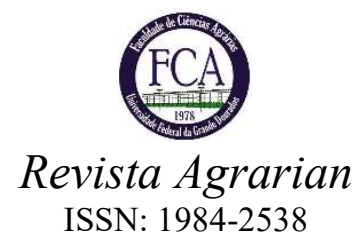

Revista Brasileira de Plantas Medicinais, v.18, n.1, p.168-171, 2016.

TERUEL, B.; CORTEZ, L.; FO, L.N. Estudo comparativo do resfriamento de laranja Valência em três sistemas de resfriamento. Revista Brasileira de Engenharia Agrícola e Ambiental, v.5, n.3, p.481-486, 2004.

THEWES, F. R.; BRACKMANN, A.; SCHULTZ, E. E.; MACHADO, E. P.; LUDWIG, V.; SANTOS, L. F. Controlled atmosphere maintains native and cultivated yerba mate quality during shelf life after long-term storage. Bragantia v.75, n.2, p.230-239, 2016.

TSANG, M. and FURUTANI, S. A low cost hydrocooling unit for horticultural commodities. Journal Hawaii Pacific Agriculture, v.14, n.1, p.1-14, 2006. 